\title{
SISTEM PENDETEKSI POLA TAJWID AL- QUR'AN HUKUM IKHFA SYAFAWI DAN IDGHAM MIMI PADA CITRA MENGGUNAKAN METODE EUCLID DISTANCE DAN BRAY CURTIS DISTANCE
}

\author{
Defry Hamdhana ${ }^{(1)}$, Fadlisyah ${ }^{(2)}$, Safira Adani ${ }^{(3)}$ \\ Teknik Informatika \\ Jl. Cot Tgk Nie-Reulet, Aceh Utara, 141 Lhokseumawe \\ e-mail : defryhamdhana@unimal.ac.id
}

\begin{abstract}
Abstrak
Al-Qur'an adalah Kalamullah, sebagai mu'jizat, yang telah diturunkan kepada penutup para Nabi dan Rasul, Muhammad dengan perantara Jibril yang termaktub dalam mushaf-mushaf yang dinukil sampai kepada kita secara mutawatir, membacanya sebagai ibadah, yang dimulai dengan surah Al-Fatihah yang ditutup dengan surah An-Nas. Untuk membaca Al-Qur'an diperlukan pengetahuan tentang pedoman ilmu Tajwid. Dalam penelitian ini, metode Euclid Distance dan Bray Curtis Distance digunakan untuk menghitung jarak keakurtan pola Tajwid pada citra Al-Qur'an. Hasil pengujian menunjukan bahwa keakuratan sistem ini sebesar $70 \%$ hingga $90 \%$. Persentase detection rate tersebut menunjukkan bahwa metode Euclid Distance dan Bray Curtis Distance dapat digunakan sebagai salah satu pendekatan untuk pendeteksian pola Tajwid pada citra Al-Qur'an, akan tetapi dari segi hasil Big Theta menyatakan bahwa algoritma Euclid Distance lebih efisien karena memiliki jumlah Big Theta yang lebih kecil dari Bray Curtis Distance. Sistem ini memiliki beberapa kelemahan yaitu memiliki false positive rate yang tinggi, dapat dilihat pada unjuk kerja dari sistem pendeteksi Tajwid ini, proses keakurasiannya dapat dilakukan dengan memberikan pelatihan lebih lanjut dengan tambahan data training yang lebih banyak dan lebih bervariasi, dan inputan sampel bisa berupa citra Al-Qur'an selain dari surat Al-Baqarah. Walaupun begitu, sistem deteksi Tajwid ini tidak menafikan pentingnya guru untuk membimbing dalam belajar cara baca sesuai dengan hukum-hukum Tajwid yang benar.
\end{abstract}

Kata Kunci : Pengolahan Citra, Al-Qur'an, Tajwid, Euclid Distance, Bray Curtis Distance, Big Theta. 


\section{Pendahuluan}

Setiap muslim memiliki landasan hukum yaitu Al-Qur'an dan Hadist. Al-Qur'anul Karim adalah Kalamullah, Kitab suci yang agung umat Islam dan Al-Qur'an ditulis dalam bahasa Arab. Sebagian besar Muslim di seluruh dunia mengetahui bagaimana cara membaca AlQur'an, tetapi tidak semua umat Islam dapat membaca Al-Qur'an dengan benar berdasarkan makhraj dan Tajwid. Hukum makhraj dan Tajwid adalah pedoman dalam membaca Al-Qur'an. Makhraj secara bahasa berarti tempat keluarnya huruf. Adapun secara istilah adalah tempat keluarnya suara huruf hijaiyah mulai dari alif sampai ya'. Pengertian Tajwid menurut bahasa (ethimologi) adalah memperbaiki atau memperindah sesuatu. Sedangkan menurut istilah, Ilmu Tajwid adalah pengetahuan tentang kaidah serta cara-cara membaca Al-Qur'an dengan sebaik-baiknya. Hal Ini adalah wajib bagi umat Islam untuk membaca Al-Qur'an berlandaskan pada makhraj yang tepat dan Tajwid yang baik. Hal ini dikarenakan, hanya sedikit saja perbedaan bunyi huruf dalam bahasa Arab bisa menyebabkan arti yang berbeda dari kata tersebut.

Orang yang membaca Al-Qur'an umumnya akan merujuk kepada seorang guru yang ahli dalam makhraj dan Tajwid bacaan Al-Qur'an yang disebut ustadz. Seorang ustadz akan mengamati setiap hukum makhraj dan Tajwid yang sedang dibaca, kemudian mengingatkan kembali hukum yang tepat apabila terjadi kesalahan dalam pembacaan. Saat ini, ada beberapa perangkat lunak pembelajaran Al-Qur'an yang tersedia di pasaran. Kegunaan software ini, pengguna hanya dapat membaca Al-Qur'an, namun penempatan hukum Tajwid tidak ditampilkan.

Dalam penelitian ini, penulis mengembangkan sistem yang menggunakan kombinasi citra surat Al-Qur'an latih sebagai input data untuk mendapatkan pola Tajwid yang sesuai dengan membandingkan input citra surat Al-Qur'an uji. Citra yang diuji nantinya akan terdeteksi bagian-bagian mana yang terkandung Tajwid di dalamnya sehingga pengguna dapat dengan mudah membaca dan memahami Tajwid tersebut.

\section{Metode Penelitian}

\subsection{Metode Euclid Distance}

Euclid distance adalah matrika yang paling sering digunakan untuk menghitung kesamaan dua vektor. Euclid distance menghitung akar dari kuadrat perbedaan dua vektor (root of square differences between two vectors).

DOI: https://doi.org/10.29103/techsi.v10i2.886 
Rumus Euclid Distance:

Keterangan:

$$
D_{\text {EUCLID }}=\sqrt{(a+b)}
$$

$\mathrm{a}=$ nilai vektor $\mathrm{i}$ dan $\mathrm{j}$ menunjukkan jumlah koordinat dari $(1,1)$

$\mathrm{b}=$ nilai vektor $\mathrm{i}$ dan $\mathrm{j}$ menunjukkan jumlah koordinat dari $(0,1)$

Kesamaan biner (binary similarity) dan ketidaksamaan jarak (dissimilarity) merupakan tindakan dalam masalah analisis pola seperti klasifikasi, clustering, dan lain-lain. Karena kinerja bergantung pada pilihan yang sesuai ukuran, banyak peneliti telah mengambil upaya yang rumit untuk menemukan kesamaan biner yang paling bermakna. Dapat dimisalkan dua benda atau pola, yakni (i dan j) adalah diwakili oleh bentuk fitur vektor biner. Misalkan $\mathrm{n}$ jumlah fitur (atribut) atau dimensi fitur vektor. Dapat dilihat bahwa vektor " $\mathrm{i}$ " diperoleh dari hasil latih Sedangkan vektor " $j$ " diperoleh dari hasil uji. Definisi kesamaan biner dan jarak yang ditunjukkan oleh Operasional Unit taksonomi (Otus) seperti yang terlihat pada Tabel 2.1 yang mana atribut " a " sejumlah fitur nilai-nilai $i$ dan $j$ keduanya bernilai $(1,1)$, atau keberadaan yang berarti 'positif'. Atribut " $b$ " adalah jumlah atribut dimana nilai i dan $j$ adalah $(0,1)$, yang berarti 'tidak adanya kesesuaian'. Atribut " $c$ " adalah jumlah atribut di mana nilai $\mathrm{i}$ dan $\mathrm{j}$ adalah $(1,0)$, yang berarti $\mathrm{j}$ adanya kesesuaian dan atribut " $d$ " adalah jumlah atribut di mana kedua $i$ dan $j$ memiliki nilai $(0,0)$ atau tidak adanya, yang berarti 'negatif'. Diagonal Singkat yang menjadi titik total keseluruhan "SUM" yaitu Jumlah total a $+b+c+d$ selalu sama dengan $n$. (Seong-seok chui, 2010).

Tabel 2.1. OTUs Expressions of Binary Intances $i$ and $j$

\begin{tabular}{|c|c|c|c|}
\hline $\mid \mathrm{i}$ & 1 (Presence) & 0 (Absence) & Sum \\
\hline 1 (Presence) & $a=i \bullet j$ & $b=\bar{\imath} \bullet j$ & $a+b$ \\
\hline 0 (Absence) & $c=i \cdot \bar{j}$ & $d=\bar{\imath} \bullet \bar{\jmath}$ & $c+d$ \\
\hline Sum & $a+c$ & $b+d$ & $n=a+b+c+d$ \\
\hline
\end{tabular}

Berdasarkan tabel Otus dan metode Euclid Distace maka untuk mengolah dan mensimulasikan proses deteksi pola Tajwid hukum Ikhfa Syafawi dan Idgham Mimi, vektor pola dari hukum bacaan Al-Qur'an 
tersebut yang akan dilatih terlebih dahulu diketahui atau dikenali. Pembentukan vektor pola Tajwid yang dibangun menggunakan ciri sebagai berikut:

Tabel 2.2. Vektor Pola Tajwid

\begin{tabular}{|c|c|}
\hline Pola Tajwid & $\begin{array}{c}\text { Huruf Hijayyah } \\
\text { Ikhfa Syafawi }\end{array}$ \\
\hline$(\dot{\rho})$ & + \\
\hline Pola Tajwid & Idgham Mimi \\
\hline$(\dot{)})$ & $r$ \\
\hline
\end{tabular}

\subsection{Metode Bray Curtis Distance}

Bray Curtis Distance disebut juga dengan Sorensen Distance adalah metode normalisasi yang banyak digunakan dalam ilmu tumbuhtumbuhan, ekologi dan ilmu lingkungan. The Bray Curtis Distance memiliki properti jika nilai yang dibandingkan positif dan nilai-nilainya akan berada di antara 0 (nol) dan 1 (satu)

Zero Bray Curtis Distance menandakan kesamaan, jika kedua objek sama nilainya nol akan menyebabkan pembagian dengan nol, maka untuk kasus ini perlu didefinisikan sebelumnya.

Rumus Bray Curtis Distance:

Keterangan:

$$
D_{\text {BRAY CURTIS }}=\frac{\mathrm{a}+\mathrm{b}}{2 \mathrm{a}+\mathrm{b}+\mathrm{c}}
$$

$\mathrm{a}=$ nilai vektor $\mathrm{i}$ dan $\mathrm{j}$ menunjukkan jumlah koordinat dari $(1,1)$

$\mathrm{b}=$ nilai vektor $\mathrm{i}$ dan $\mathrm{j}$ menunjukkan jumlah koordinat dari $(0,1)$

$\mathrm{c}=$ nilai vektor $\mathrm{i}$ dan $\mathrm{j}$ menunjukkan jumlah koordinat dari $(1,0)$

Tabel 2.3. OTUs Expressions of Binary Intances $i$ and $j$

\begin{tabular}{|c|c|c|c|}
\hline & 1 (Presence) & 0 (Absence) & Sum \\
\hline 1 (Presence) & $a=i \bullet j$ & $b=\bar{\imath} \bullet j$ & $a+b$ \\
\hline 0 (Absence) & $c=i \bullet \bar{\jmath}$ & $d=\bar{\imath} \bullet \bar{\jmath}$ & $c+d$ \\
\hline Sum & $a+c$ & $b+d$ & $n=a+b+c+d$ \\
\hline
\end{tabular}


Berdasarkan tabel Otus dan metode Euclid Distace maka untuk mengolah dan mensimulasikan proses deteksi pola Tajwid hukum Ikhfa Syafawi dan Idgham Mimi, vektor pola dari hukum bacaan Al-Qur'an tersebut yang akan dilatih terlebih dahulu diketahui atau dikenali. Pembentukan vektor pola Tajwid yang dibangun menggunakan ciri sebagai berikut:

Tabel 2.4. Vektor Pola Tajwid

\begin{tabular}{|c|c|}
\hline Pola Tajwid & $\begin{array}{c}\text { Huruf Hijayyah } \\
\text { Ikhfa Syafawi }\end{array}$ \\
\hline$(\dot{\overrightarrow{ }})$ & + \\
\hline Pola Tajwid & Idgham Mimi \\
\hline$(\dot{\overrightarrow{ }})$ & $r$ \\
\hline
\end{tabular}

\subsection{Metode Euclid Distance}

Skema sistem adalah struktur dan mekanisme untuk menghubungkan sekumpulan unsur atau elemen yang saling berkaitan dan saling mempengaruhi dalam melakukan kegiatan bersama untuk mencapai suatu tujuan.

Skema sistem untuk pengenalan pola yang dirancang dalam penelitian ini diilustrasikan pada Gambar 2.1

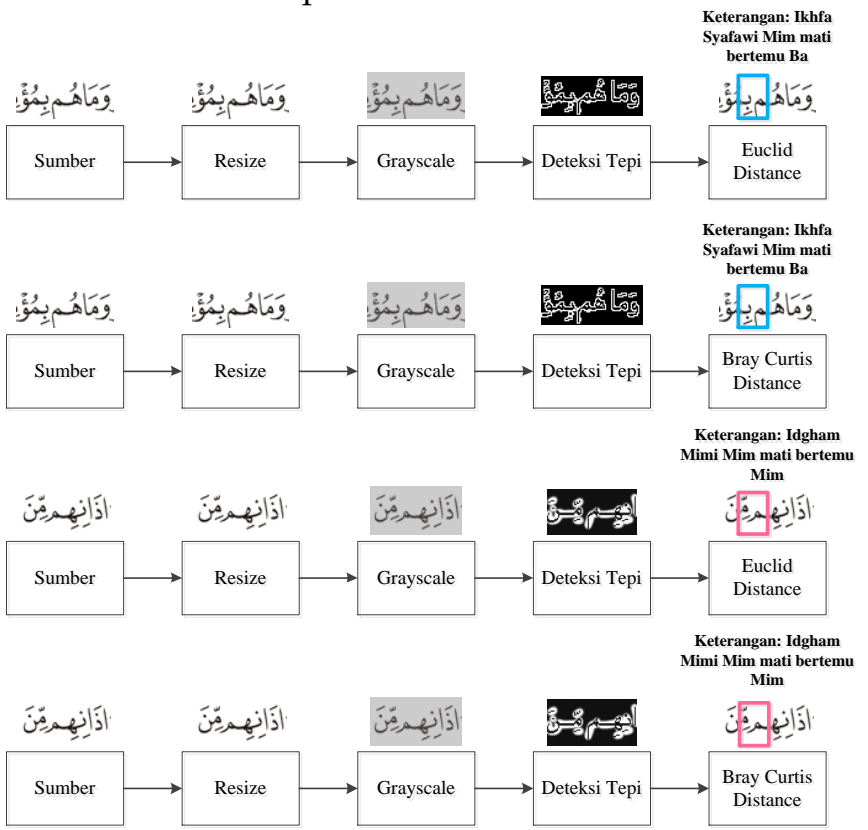

Gambar 2.1 Skema Sistem Secara Keseluruhan 
Berdasarkan gambar 2.1 ada beberapa tahapan-tahapan yang dapat dilakukan, yaitu:

1. Input gambar (image) yang berformat citra.bmp. yakni disebut sebagia citra asli dan dimisalkan sebagai sumber yang akan diproses ke tahap selanjutnya.

2. Sumber atau citra asli yang telah diinput terlebih dahulu di resize sesuai dengan format yang ditentukan, konsep dasar mengenai hal ini berfungsi untuk mempercepat proses pendeteksian.

3. Tahap grayscale adalah proses pengolahan citra dengan cara mengubah nilai-nilai piksel awal citra (sumber/citra asli) menjadi sebuah citra keabuan yang berfungsi untuk memudahkan proses perhitungan pada operasi berikutnya, karena nilai-nilai piksel pada citra keabuan tersebut dapat direpresentasikan dalam sebuah matriks.

4. Pada tahapan konvolusi dilakukan untuk memdeteksi daerah tepi citra yang bertujuan untuk menandai bagian yang menjadi detail citra dan memperbaiki detail dari citra yang kabur, yang terjadi karena error atau adanya efek dari proses akuisisi citra.

5. Tahap ini adalah memperkuat dan memperakurat proses-proses sebelumnya dengan metode Euclid Distance dan Bray Curtis Distance untuk mendeteksi pola hukum Tajwid Ikhfa Syafawi dan Idgham Mimi.

\section{Hasil dan Pembahasan}

\subsection{Hasil Deteksi Pola Tajwid}

Hasil deteksi pola Tajwid adalah suatu proses yang menunjukkan pola Tajwid yang sudah dilatih sebelumnya dikenali atau terdeteksi pada saat pengujian. Hasil deteksi pola Tajwid yang didapatkan berdasarkan proses pelatihan sample mecakup pola Tajwid hukum Ikhfa Syafawi dan Idgham Mimi yang ditunjukkan pada tabel 3.1, sehingga pola Tajwid yang telah diuji menampilkan hasil deteksi yang sesuai maupun cocok. 
Tabel 3.1 Hasil Deteksi Pola Tajwid Ikhfa Syafawi dan Idgham Mimi yang Benar

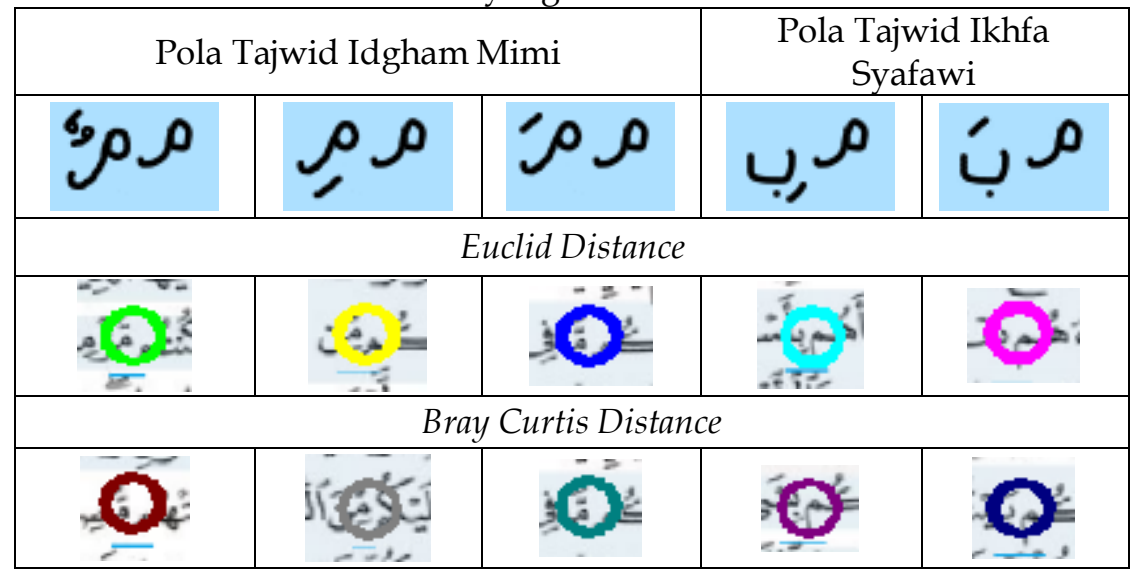

Tabel 3.2 Hasil Deteksi Pola Tajwid Ikhfa Syafawi dan Idgham Mimi yang Salah

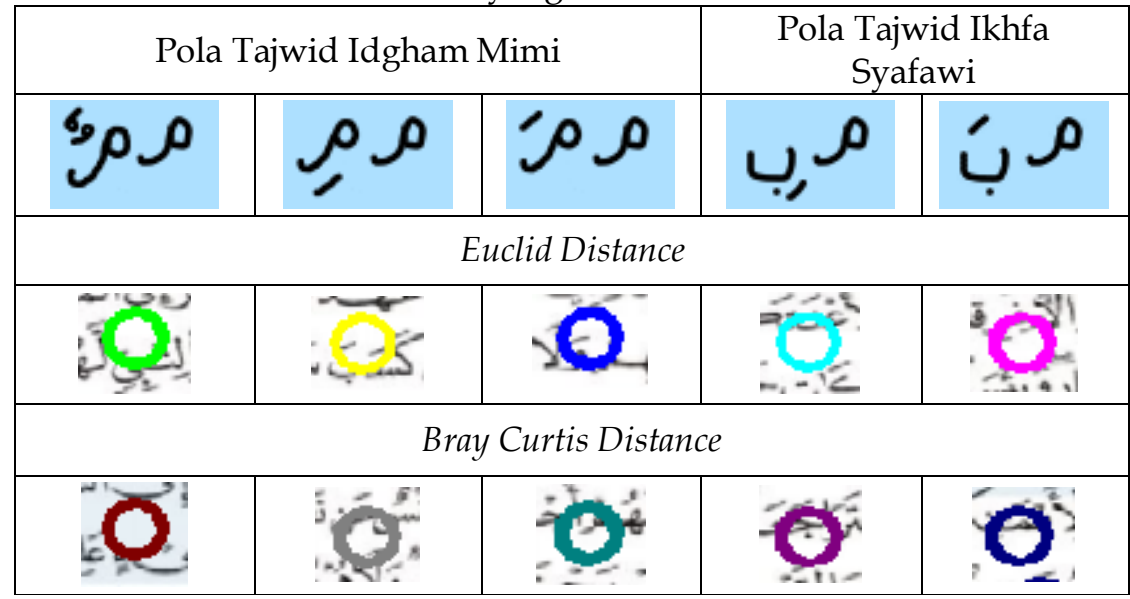

\subsection{Pengukuran Unjuk Kerja Sistem Pola Tajwid}

Pengukuran unjuk kerja sistem adalah analisa peneliti untuk mengukur keakuratan kerja sistem deteksi citra pola Tajwid ini dengan melakukan pelatihan pada setiap pola Tajwid Ikhfa Syafawi dan Idgham Mimi di dalam surat Al-Baqarah yang kemudian diuji, sehingga dapat diketahui tingkat kebenaran maupun kesalahan deteksi pola Tajwid tersebut. Tabel 4.5 dan 4.6 menunjukkan hasil unjuk kerja sistem pendeteksi pola Tajwid yang dapat dilihat di bawah ini: 
Tabel 3.3 Hasil Unjuk Kerja Sistem Pendeteksi Citra Pola Tajwid Ikhfa Syafawi dan Idgham Mimi Metode Euclid Distance

\begin{tabular}{|c|c|c|c|c|c|c|}
\hline No & $\begin{array}{c}\text { Citra Pola } \\
\text { Tajwid }\end{array}$ & $\begin{array}{l}\text { Jumlah } \\
\text { Citra } \\
\text { Pengujian }\end{array}$ & $\begin{array}{c}\text { Jumlah } \\
\text { Citra } \\
\text { yang } \\
\text { Terdeteks } \\
\text { i } \\
\end{array}$ & $\begin{array}{l}\text { False } \\
\text { Positi } \\
\text { ve } \\
\text { Rate }\end{array}$ & $\begin{array}{c}\text { Detect } \\
\text { ion } \\
\text { Rate }\end{array}$ & $\begin{array}{l}\text { Perse } \\
\text { ntase }\end{array}$ \\
\hline 1 & $\begin{array}{c}\text { Ikhfa Syafawi } \\
\text { (Kasrah) }\end{array}$ & & 8 & 2 & 8 & $80 \%$ \\
\hline 2 & $\begin{array}{c}\text { Ikhfa Syafawi } \\
\text { (Fattah) }\end{array}$ & 10 & 9 & 1 & 9 & $90 \%$ \\
\hline 3 & $\begin{array}{c}\text { Idgham Mimi } \\
\text { (Kasrah) }\end{array}$ & 10 & 8 & 2 & 8 & $80 \%$ \\
\hline 4 & $\begin{array}{l}\text { Idgham Mimi } \\
\text { (Fattah) }\end{array}$ & 10 & 7 & 3 & 7 & $70 \%$ \\
\hline 5 & $\begin{array}{c}\text { Idgham Mimi } \\
\text { (Dhammah) }\end{array}$ & 10 & 9 & 1 & 9 & $90 \%$ \\
\hline
\end{tabular}


Tabel 3.4 Hasil Unjuk Kerja Sistem Pendeteksi Citra Pola Tajwid Ikhfa Syafawi dan Idgham Mimi Metode Bray Curtis Distance

\begin{tabular}{|c|c|c|c|c|c|c|}
\hline No & Citra Pola Tajwid & $\begin{array}{c}\text { Jumlah } \\
\text { Citra } \\
\text { Pengujian }\end{array}$ & $\begin{array}{c}\text { Jumlah } \\
\text { Citra } \\
\text { yang } \\
\text { Terdete } \\
\text { ksi } \\
\end{array}$ & $\begin{array}{l}\text { False } \\
\text { Positi } \\
\text { ve } \\
\text { Rate }\end{array}$ & $\begin{array}{c}\text { Detect } \\
\text { ion } \\
\text { Rate }\end{array}$ & $\begin{array}{c}\text { Persen } \\
\text { tase }\end{array}$ \\
\hline 1 & $\begin{array}{l}\text { Ikhfa Syafawi } \\
\text { (Kasrah) }\end{array}$ & 10 & 8 & 2 & 8 & $80 \%$ \\
\hline 2 & $\begin{array}{c}\text { Ikhfa Syafawi } \\
\text { (Fattah) }\end{array}$ & 10 & 7 & 3 & 7 & $70 \%$ \\
\hline 3 & $\begin{array}{c}\text { Idgham Mimi } \\
\text { (Kasrah) }\end{array}$ & & 9 & 1 & 9 & $90 \%$ \\
\hline 4 & $\begin{array}{c}\text { Idgham Mimi } \\
\text { (Fattah) }\end{array}$ & 10 & 9 & 1 & 9 & $80 \%$ \\
\hline 5 & $\begin{array}{c}\text { Idgham Mimi } \\
\text { (Dhammah) }\end{array}$ & 10 & 9 & 1 & 9 & $90 \%$ \\
\hline
\end{tabular}

\section{Kesimpulan}

Kesimpulan pada penilitian ini didapatkan dari beberapa proses pelatihan dan pengujian berdasarkan sampel citra Al-Qur'an untuk mendeteksi pola Tajwid hukum bacaan Ikhfa Syafawi dan Idgham Mimi yang terdapat di surat Al-Baqarah dengan menggunakan dua metode yaitu Euclid Distance dan Bray Curtis Distance, maka hasil yang diperoleh dari beberapa proses penelitian dapat dirincikan sebagai berikut:

1. Research (penelitian) ini menunjukkan bahwa sistem pendeteksi pola Tajwid Al-Qur'an hukum bacaan Ikhfa Syafawi dan Idgham Mimi pada citra menggunakan metode Euclid Distance dan Bray Curtis 
Distance memiliki rata-rata detection rate yang berkisar dari $70 \%$ hingga 90\%. Berdasarkan hasil persentase detection rate tersebut menyatakan bahwa kedua metode ini dapat digunakan sebagai salah satu pedekatan pola-pola Tajwid Al-Qur'an dan mampu bekerja dengan baik.

2. Jumlah banyaknya sampel yang dilatih atau diuji mempengaruhi keakuratan sistem pedeteksi.

3. Dengan menggunakan metode Euclid Distance dan Bray Curtis Distance sistem pendeteksian pola Tajwid Ikhfa Syafawi dan Idgham Mimi lebih mudah terdeteksi jika citra hasil scanner tidak pecah dan tampak lebih jelas.

4. Sampel citra Tajwid yang dijadikan pelatihan sangat berdampak terhadap tingginya persentase keberhasilan pendeteksian masingmasing pola. Sebagai inputannya sistem ini hanya ditujukan pada citra pola Tajwid Ikhfa Syafawi dan Idgham Mimi saja yang terdapat pada surat Al-Baqarah.

5. Faktor faktor kemiripan maupun perbedaan setiap citra pola Tajwid Ikhfa Syafawi dan Idgham Mimi menjadi salah satu kelemahan pada sistem ini, karena sistem pedeteksian memliki nilai sensitifitas yang sangat tipis terhadap vektor-vektor pola Tajwid tersebut sehingga false positive rate akan muncul.

6. Sistem pendeteksi citra pola Tajwid Ikhfa Syafawi dan Idgham Mimi menggunakan metode Euclid Distance dan Bray Curtis Distance memiliki false positive rate yang tinggi atau memiliki peluang error berkisar $30 \%$.

7. Kelebihan pada sistem pendeteksi pola Tajwid Al-Qur'an ini bisa dilakukan pendeteksian dengan inputan sampel selain citra surat $\mathrm{Al}$ Baqarah maupun dengan pola hukum Tajwid yang berbeda dari pola Tajwid Ikhfa Syafawi dan Idgham Mimi.

Saran bertujuan untuk membangun pengembangan penilitian pada sistem ini yang akan dilakukan oleh peneliti-peneliti selanjutnya, sehingga manfaat ilmu yang telah didapat terus berkesinambungan. Berdasarkan penelitian yang telah dilakukan ada beberapa saran dari penulis yaitu:

1. Berdasarkan penelitian yang sudah dilakukan ini dapat dimanfaatkan dari hasilnya untuk membangun sistem pendeteksian tiap-tiap pola hukum Tajwid lain dengan acuan masing-masing ketentuan huruf arabnya di dalam Al-Qur'an sampai titik terciptanya sebuah aplikasi pendeteksi Tajwid dengan tersedianya hukum-hukum yang lengkap.

DOI: https://doi.org/10.29103/techsi.v10i2.886 
2. Sistem pendeteksi citra pola Tajwid Ikhfa Syafawi dan Idgham Mimi menggunakan metode Euclid Distance dan Bray Curtis Distance bisa menjadi pedoman berkembangnya research mengenai deteksi Tajwid Al-Qur'an dengan hukum yang berbeda-beda.

3. Sistem ini juga tidak bisa memungkiri pentingnya guru untuk memahami ketentuan hukum bacaan Tajwid Al-Qur'an yang baik dan benar, agar dapat mengantisipasi kesalahpahaman terhadap teori pembelajaran Tajwid Al-Qur'an.

4. Selain itu, sistem pendeteksi Tajwid Al-Qur'an ini juga bisa dibangun dan dikembangkan menggunakan video (webcam), atau bahkan diterapkan pada aplikasi website sehingga semua orang yang ingin mempelajari hukum-hukum Tajwid Al-Qur'an kedepannya dengan mudah mengakses deteksi Tajwid dimanapun dan kapanpun.

\section{DAFTAR PUSTAKA}

Achmad Balza, Firdausy Kartika, 2013. Pengolahan Citra Digital Menggunakan Delphi. Yogyakarta: Andi.

Al Abror Ma'sum, 2015. Belajar Praktis Ilmu Tajwid. Jakarta: Pandom Medua Nusantara.

Asma Nur, 2011. Sistem Pendeteksian Wajah Pada Video Menggunakan Pendekatan Jaringan Saraf Tiruan. Prodi Teknik Informatika Fakultas Teknik Universitas Malikussaleh. Reuleut-Aceh Utara.

Fadhilah Cut, 2015. Sistem Pendeteksi Pola Tajwid Al-Qur'an Hukum Idgham Bi-Ghunnah Dan Bilaghunnah Pada Citra Menggunakan Metode Nei And Li. Prodi Teknik Informatika Fakultas Teknik Universitas Malikussaleh. Reuleut-Aceh Utara.

Fadlisyah, 2007. Computer Vision Dan Pengolahan Citra. Yogyakarta: Andi.

Kadir Abdul, 2013. Dasar pengolahan citra dengan Delphi. Yogyakarta: Andi.

Nargaza Juanda, 2013. Pengenalan Pola Tanda Tangan Menggunakan Transformasi Slant. Prodi Teknik Informatika Fakultas Teknik Universitas Malikussaleh. Reuleut-Aceh Utara.

Sutabri Tata, 2012. Analisis Sistem Informasi. Penerbit Andi. Yogyakarta. Wayan Suartika E. P I, Yudhi Wijaya Arya, dkk, 2016. Klasifikasi Citra Widodo, P. P., dan Herlawati, 2011. Menggunakan UML. Informatika Bandung. Bandung.

Ya'la Kurnaedi Lc Abu, 2014. Tajwid Lengkap Asy-Syafi'i. Jakarta: Pustaka Imam Asy-Syafi'i. 